\title{
Anatomical assessment of the palatal mucosa for connective tissue grafts
}

\author{
Sun-Kyoung Yu, Jin Woong Lim, Yonghwa Cho, Heung-Joong Kim*
}

Department of Oral Anatomy, College of Dentistry, Chosun University, Gwangju, Korea

\begin{abstract}
The palatal mucosa and gingiva are histologically similar, hence used as an autologous donor site for connective tissue grafts in periodontal surgery. Therefore, the aims of this study were to investigate the palatal mucosa to obtain a histological quantitative data, and to compare the topographic relationship of the greater palatal artery (GPA) with the greater palatine nerve (GPN). The 32 hemimaxillae in Korean were prepared using conventional methods of tissue processing and stained with hematoxylin-eosin. The obtained specimens were measured for the presence of the areas of entire palatal mucosa, submucosa and glandular tissue, the length from the alveolar crest to the GPA and the GPN, and the depth from the mucosal surface to each artery and nerve. The mean area of the entire palatal mucosa was $59.7,53.2,50.6,57.6$, and $73.2 \mathrm{~mm}^{2}$ and that of the submucosa was $36.6,35.3,33.3,41.8$, and $58.0 \mathrm{~mm}^{2}$ according to the tooth position from the canine, respectively. The glandular tissues were found in all the molars and the mean area was 15.1 (first molar) and 30.3 (second molar) $\mathrm{mm}^{2}$, respectively. The GPA with an average of $10.1 \mathrm{~mm}$ was located on the lateral side than the GPN with an average of $10.8 \mathrm{~mm}$, but there was no statistically significant difference. Whereas, the depth of the GPA was $4.3 \mathrm{~mm}$, which was statistical significantly deeper than that of the GPN ( $3.7 \mathrm{~mm}$ under the mucosal surface). These anatomical results provided the quantitative data on the palatal mucosa as an autologous donor site for connective tissue grafts.
\end{abstract}

Key Words: Palatal mucosa, Lamina propria, Submucosa, Greater palatine artery, Greater palatine nerve

(c) This is an open-access article distributed under the terms of the Creative Commons Attribution Non-Commercial License (http://creativecommons.org/licenses/by-nc/4.0) which permits unrestricted noncommercial use, distribution, and reproduction in any medium, provided the original work is properly cited.

\section{서 론}

사람의 구강점막(oral mucosa)은 매우 다양한 특징을 보이 는데, 조직의 유형에 따라 유사한 구성 양상을 가진다[1,2]. 입 천장 점막(palatal mucosa)은 씹기점막(masticatory mucosa) 으로, 음식을 씹을 때 압박 및 전단력을 받게 되고 마모될 수 있 다[1]. 입천장 점막의 조직학적 구성을 살펴보면, 크게 세 층으 로 구분된다. 먼저, 구강상피(oral epithelium)는 다른 부위에 비하여 상대적으로 두꺼운 각질화된 중층편평상피(keratinized stratified squamous epithelium)로 이루어져 마모에 잘 견딜 수 있다[3]. 그 아래에는 이를 지지해주는 결합조직(connective tissue)인 고유판(lamina propria)이 있다. 이는 풍부한 모세혈 관 고리를 포함하고 있으며 상피를 향하여 굴곡이 심한 긴 유두 를 내어 전단력이 가해질 때 상피가 고유판으로부터 박리되는 것을 막아주는 유두층(papillary layer)과 그 아래 상피 표면과 평행한 많은 아교섬유(collagen fiber)를 포함하고 있어 충격에 견딜 수 있도록 해주는 그물층(reticular layer)으로 다시 나눌 수 있다[1,4,5]. 이 두 층 아래에 이러한 점막을 지배하는 신경 과 큰 혈관을 함유하는 성긴 지방조직(adipose tissue)이나 샘조 직(glandular tissue)을 함유하는 섬유성 점막밑층(submucosa layer)이 있어 아래 있는 뼈로부터 구강점막을 분리시키고 기계 적 압력에 대한 완충 작용을 한다[1,2]. 또한 샘조직은 점막 표면

Received June 5, 2018; Revised August 5, 2018; Accepted August 6, 2018

Corresponding author: Heung-Joong Kim, Department of Oral Anatomy, College of Dentistry, Chosun University, 303, Pilmun-daero, Donggu, Gwangju 61452, Korea.

Tel: +82-62-230-6875, Fax: +82-62-224-3706, E-mail: hjbkim@chosun.ac.kr

Copyright (๑) 2018, Oral Biology Research Institute 
에 도관을 직접 내어 쉬지 않고 천천히 분비되어 큰 침샘이 기능 을 하지 않는 밤에 특히 구강점막을 보호하고 적셔주는데 중요 한 역할을 한다[3].

이러한 입천장 점막은 잇몸과 매우 유사한 특징을 가지고 있 어, 치과 임상에서 치주 수술 시 결합조직을 얻기 위한 자가 이 식 부위로 사용된다. 이때 얻어진 이식편의 두께에 따라 혈관의 재형성 또는 조직의 위축 여부 및 치료 기간 등에 영향을 미친 다[6]. 즉, 적절한 두께의 입천장 점막을 얻는 것이 치료 방법과 예후에 매우 중요하기 때문에, 많은 연구자들이 다양한 방법을 이용하여 입천장 점막의 두께를 평가하였다[7-10]. 최근 $\mathrm{Yu}$ 등 [11,12]은 시신에서 직접 입천장 점막의 두께를 계측하고 조직 표본을 만들어 전체 입천장 점막과 고유판을 구분하여 치아 부 위에 따른 상세한 자료를 제시하였다. 이러한 이전 연구들에서 입천장 점막의 두께에 관한 적절한 연구가 진행되었으나, 입천 장 점막의 고유판, 지방조직 및 샘조직의 분포와 구성에 관한 자 료는 여전히 부족하다.

성공적인 수술과 이식편의 크기를 결정하는 또 다른 중요한 해부학적 요인으로 단단입천장에 주요한 혈액을 공급하는 큰입 천장동맥(greater palatine artery)의 위치와 경로가 중요하다 $[13,14]$. 큰입천장동맥은 큰입천장신경(greater palatine nerve) 과 함께 신경혈관다발(neurovascular bundle)을 형성하며, 단 단입천장 뒤모서리 약 $4 \mathrm{~mm}$ 앞의 셋째 큰어금니 부위의 큰입천 장구멍(greater palatine foramen)을 통해 나와 앞쪽으로 주행 한다. 이후 앞니관(incisive canal)을 통하여 나오는 나비입천장 동맥(sphenopalatine artery)의 가지와 문합을 이루며 입천장 쪽 잇몸, 샘조직 및 지방조직에 분포한다[13,15].

특히, 이 둘은 큰입천장구멍 앞쪽 어금니부위에 위치하는 뼈 구조물인 입천장가시(palatal spine)에 의해 형성된 고랑을 따라 주행하는데, 큰입천장동맥은 가쪽고랑으로 큰입천장신경은 안 쪽고랑을 따라 주행하여, 치주 수술 및 치과 마취 시 입천장가시 의 촉진을 통하여 동맥과 신경의 손상을 예방할 수 있다[16,17]. 그러나 최근 연구에 의하면 큰입천장동맥은 입천장쪽 잇몸에 분포하는 중심 가지인 가쪽가지와 샘조직과 지방조직에 분포하 는 작은 안쪽가지로 나뉘며, 큰입천장신경은 안쪽고랑을 따라 주행하기 보다는 동맥보다 안쪽에서 점막 표면 가까이 주행하 였다[18]. 이와 같이 혈관과 신경의 경로가 상이하게 나타나, 입 천장쪽 잇몸에 주요 혈액 공급 및 신경 분포를 하는 큰입천장동 맥과 큰입천장신경의 중심가지의 주행과 위치 관계에 대한 명 확한 이해가 요구된다.

따라서 본 연구에서는 이전에 이루어진 조직표본의 입천장 전체 점막 및 고유판의 두께 측정 연구에 연속하여, 입천장 점막 을 조직형태학적으로 분석하여 고유판, 지방조직 및 샘조직의 분포와 구성에 관한 정량적 자료를 제공하고, 입천장쪽 잇몸에
주요 혈액 공급 및 신경 분포를 하는 큰입천장동맥과 큰입천장 신경의 주행과 위치 관계를 조사하여 결합조직 이식을 위한 해 부학적 자료를 제공하고자 한다.

\section{대상 및 방법}

\section{재료}

본 연구는 입천장 점막을 분석하기 위하여 조선대학교 의과 대학 해부학교실에 교육용 목적으로 기증된 고정된 한국인 시 신 16 구에서 얻은 32 쪽의 위턱뼈를 사용하였다. 이들은 남자 13 구와 여자 3 구로 사망 시 연령 분포는 39세에서 73 세로 평균 57.1세였으며, 송곳니(canine)에서부터 둘째 큰어금니(second molar)까지 치아의 위치를 식별할 수 있는 위턱뼈를 선택하였 다. 이러한 연구는 의학 연구 및 윤리에 관한 헬싱키 선언에 따 라 이루어졌다.

\section{조직 처리 및 표본 제작}

얻어진 위턱뼈 표본은 탈회용액(8N formic acid and $1 \mathrm{~N}$ sodium formate)에서 2달 동안 탈회하여, 정중입천장봉합 (median palatal suture)에서 절단하여 양쪽으로 나누었다. 이 후 송곳니에서부터 둘째 큰어금니까지 각 치아의 원심면에서 정중입천장봉합에 수직이 되게 microtome blade (Feather, Osaka, Japan)를 이용하여 절단하였다. 절단된 표본은 원심면 을 기준으로 하여 통상적인 조직 처리 과정에 따라 파라핀 포매 하여 $8 \mu \mathrm{m}$ 두께의 조직절편을 얻어, hematoxylin-eosin 염색 을 시행하였다. 각 치아의 원심면에서 얻어진 조직 표본은 해당 치아로 표기하였다(예: 송곳니 원심면, 송곳니). 조직 표본은 이 미지획득프로그램(LAS Basic v4.0; Leica, Wetzlar, Germany) 이 장착된 광학현미경(EZ4HD, Leica)을 통하여 관찰하고, 촬영 된 이미지의 중첩을 통하여 이틀능선(alveolar crest)에서 정중 입천장봉합 부위까지 입천장 점막 사진을 획득하였다.

\section{측정}

획득된 조직 사진에서 이틀뼈의 장축에 수직이 되도록 이틀 능선에서 연장선을 그어 기준점 및 기준선을 설정하였다. 기준 선에서 정중입천장봉합 부위까지 전체 입천장 점막, 고유판 아 래의 점막밑층 및 점막밑층 속 샘조직의 면적을 이미지분석프 로그램(I solution capture; iMTechnology, Vancouver, BC, Canada)을 이용하여 계측하였다. 샘조직이 관찰되기 시작하는 치아 위치를 확인하고, 어금니 부위에서 물렁입천장 근육의 관 
찰 여부를 확인하였다.

$\mathrm{Yu}$ 등[18]의 연구 결과를 참고하여 큰 직경을 가지고 연속 치 아 절단면에서 일정한 주행경로를 가지며 관찰되는 큰입천장동 맥의 중심 가지인 가쪽가지와 큰입천장신경을 입천장쪽 잇몸에 주요 혈액을 공급하고 신경 분포를 하는 큰입천장동맥과 큰입 천장신경으로 설정하고, 이 둘의 신경혈관다발 형성 여부와 위 치 관계를 확인하였다. 이틀능선의 연장선과 이틀뼈의 장축이 만나는 기준점에서부터 각 동맥과 신경까지의 길이와 점막 표 면에서부터의 깊이를 계측하였다. 모든 계측 항목은 두 명의 관 찰자에 의해 설정된 계측 기준에 맞추어 다른 날 두 번 반복 측 정되었다.

\section{통계분석}

모든 통계 분석은 IBM SPSS Statistics ver. 23.0 software (IBM Co., Armonk, NY, USA)을 이용하여 시행하였다. 관찰차 내 및 관찰자 간의 신뢰도(reliability)를 측정하여 계측값의 신 뢰성을 얻었다. 일원배치분산분석(one-way ANOVA)을 이용하 여 모든 계측 항목의 치아 위치에 따른 통계적 유의성을 검사한 후 Scheeffe의 기준에 따라 사후검정을 시행하였다. 큰입천장동 맥과 큰입천장신경의 길이와 깊이 사이의 통계적 유의성을 검 증하였다. 표본 수와 분포의 제한으로 인하여 성별, 연령 및 좌 우 차이의 통계적 유의성을 얻기에 어려움이 따라, 이에 관하여 서는 통계 분석을 시행하지 않았다. 모든 계측값은 평균과 표준 편차로 나타내었으며, 유의수준 0.05 에서 이루어졌다.

Table 1. Histologic distribution area of the palatal mucosa according to tooth site

\begin{tabular}{lllllll}
\hline & \multicolumn{1}{c}{$\mathbf{C}(\mathbf{n}=7)$} & P1 (n=7) & P2 (n=11) & M1 (n=15) & M2 (n=9) & $\begin{array}{c}\text { Mean } \pm \text { standard } \\
\text { deviation }\end{array}$ \\
\hline Entire palatal mucosa & $59.7 \pm 13.6$ & $53.2 \pm 10.1$ & $50.6 \pm 14.2^{*}$ & $57.6 \pm 15.4$ & $73.2 \pm 11.9^{*}$ & $58.6 \pm 15.1$ \\
Submucosa layer & $36.6 \pm 7.7^{\mathrm{a}}(0.61)$ & $35.3 \pm 5.6^{\mathrm{b}}(0.66)$ & $33.3 \pm 10.4^{\mathrm{c}}(0.66)$ & $41.8 \pm 14.0^{\mathrm{d}}(0.73)$ & $58.0 \pm 13.4^{\mathrm{abcd}}(0.80)$ & $41.2 \pm 14.0(0.70)$ \\
Glandular tissue & & & & $15.1 \pm 9.5^{*}(0.26)$ & $30.3 \pm 16.0^{*}(0.41)$ & $26.9 \pm 6.1(0.46)$ \\
\hline
\end{tabular}

Data (in $\mathrm{mm}^{2}$ ) are mean \pm standard deviation (ratio) values.

C, canine; P1, first premolar; P2, second premolar; M1, first molar; M2, second molar.

abcd Identical superscripted letters indicate statistically significant differences among the tooth sites at the indicated measurement item $(p<0.05)$.

${ }^{*}$ Statistically significant differences between two tooth sites at the indicated measurement item $(p<0.05)$.
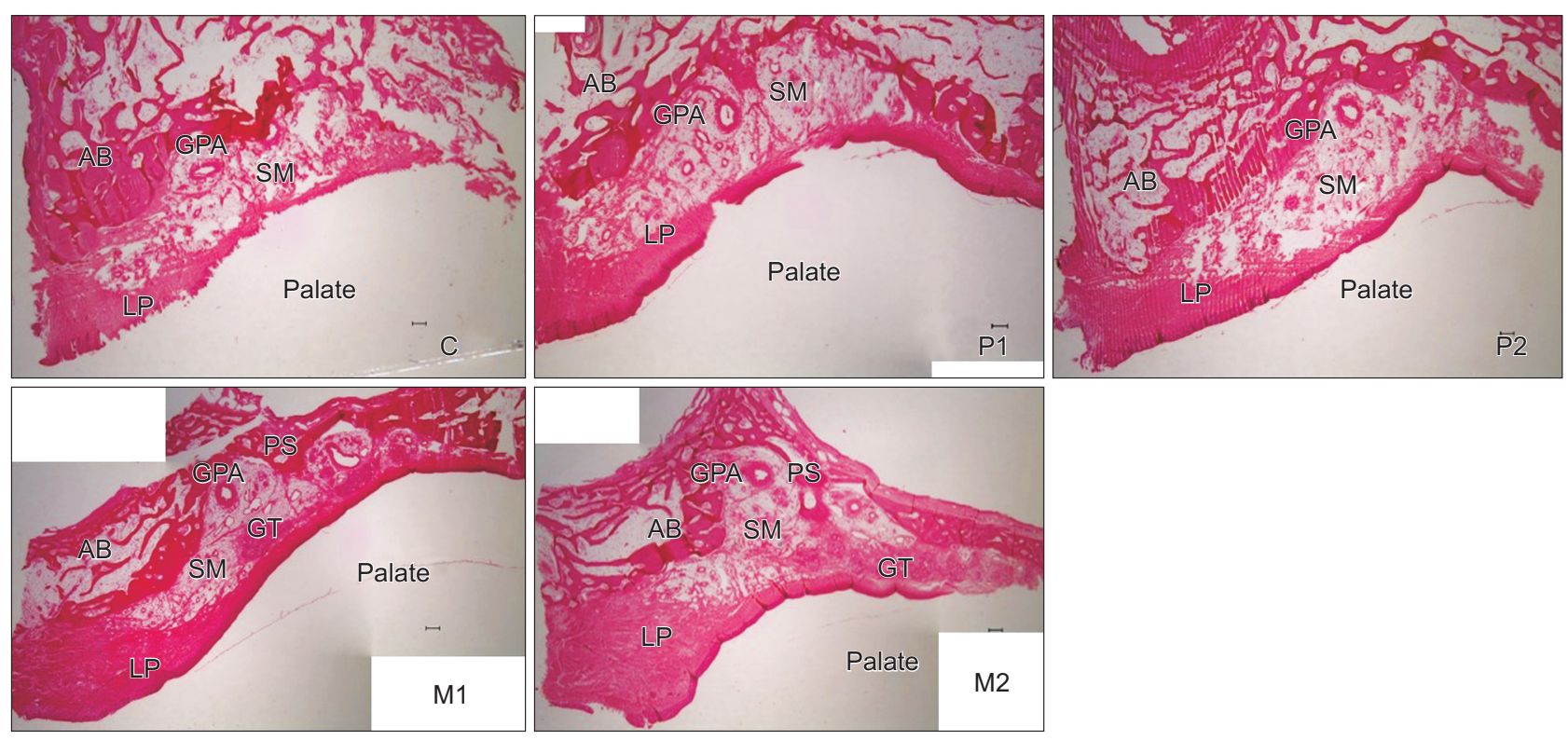

Fig. 1. Serial histologic sections of the palatal mucosa according to tooth site (H\&E stain, $\times 500 \mu \mathrm{m})$. C, canine; P1, first premolar; P2, second premolar; M1, first molar; M2, second molar. AB, alveolar bone; GPA, greater palatine artery; LP, lamina propria; SM, submucosa; GT, glandular tissue; PS, palatal spine. 


\section{결 과}

\section{입천장 점막의 조직학적 분포}

전체 입천장 점막의 평균 면적은 송곳니에서부터 치아 순서 에 따라 59.7, 53.2, 50.6, 57.6 및 $73.2 \mathrm{~mm}^{2}$ 이었다. 점막밑 층의 평균 면적은 치아 순서에 따라 $36.6,35.3,33.3,41.8$ 및 $58.0 \mathrm{~mm}^{2}$ 이었다. 점막밑층 속의 샘조직은 큰어금니에서는 모 두 발견되었으며 각각의 평균 면적은 15.1 과 $30.3 \mathrm{~mm}^{2}$ 이었고, 둘째 작은어금니에서 11쪽 중 2쪽에서만 발견되었으며 이때 샘 조직의 평균 면적은 $25.0 \mathrm{~mm}^{2}$ 이었다(Table 1, Fig. 1, 2). 전체 점막과 점막밑층 모두 송곳니에서부터 둘째 작은어금니까지 면 적이 감소하다가, 후방 큰어금니로 갈수록 샘조직이 통계적으 로 유의하게 증가함에 따라 그 면적이 크게 증가하였다.

신경과 혈관을 함유하며 이들을 보호하는 성긴 지방조직으로 구성된 점막밑층이 이틀능선에 가까운 입천장쪽 잇몸과 정중입 천장봉합 부위에서는 상대적으로 적고, 위턱뼈의 이틀돌기와 입천장뼈의 수평판이 만나 형성되는 입천장고랑의 위쪽에 집중 되어 있었다. 이때 점막밑층 속의 샘조직은 큰어금니 부위에서 입천장고랑과 정중입천장봉합 부위에 가까운 곳의 위쪽에 집중
되어 나타났으며, 물렁입천장 근육은 관찰되지 않았다(Fig. 1). 또한 치밀 결합조직으로 이루어진 고유판은 작은어금니부위에 서 일정한 면적을 가지며, 이 부위에서 점막밑층 역시 샤피섬유 (Sharpey's fibers)가 샘조직의 게재 없이 뼈막에서 고유판을 수 직으로 단단히 잡고 있었다.

\section{큰입천장동맥과 큰입천장신경의 주행}

입천장쪽 잇몸에 주요 혈액 공급과 신경 분포를 하는 큰입천 장동맥과 큰입천장신경의 중심가지는 신경혈관다발을 형성하 지 않고 각자의 주행 경로를 가졌다. 큰입천장동맥은 평균 10.1 $\mathrm{mm}$ 로 큰입천장신경의 평균 $10.8 \mathrm{~mm}$ 보다 이틀능선에 가깝게 신경보다 가쪽에 위치하였으나 통계적으로 유의하지는 않았다 $(p=0.150)$. 반면 깊이에 있어서는 큰입천장동맥은 평균 $4.3 \mathrm{~mm}$ 로 큰입천장신경의 평균 $3.7 \mathrm{~mm}$ 보다 통계적으로 유의하게 점 막 표면에서 깊이 위치하였다 $(p=0.045)$ (Table 2).

큰입천장동맥은 큰입천장신경보다 상대적으로 큰 직경과 많 은 분지를 하며 분포하였다(Fig. 3). 큰입천장구멍이 시작하는 둘째 큰어금니부위에서 입천장가시를 기준으로 큰입천장동맥 은 가쪽고랑에 큰입천장신경은 안쪽고랑에 위치하였다. 그러나
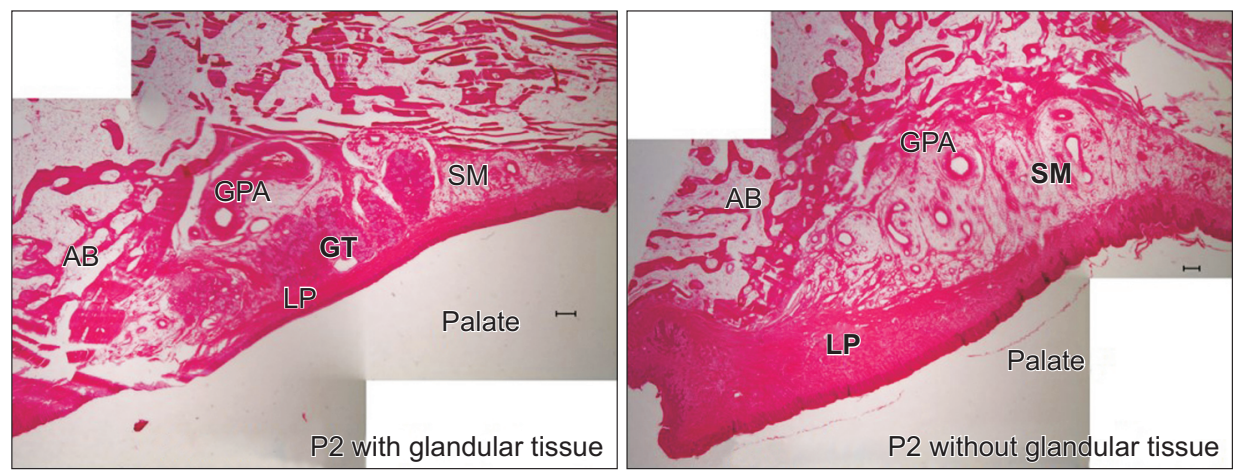

Fig. 2. Comparison of two other histologic specimens of the palatal mucosa at the second premolar (P2) with or without glandular tissue $(\mathrm{H} \& \mathrm{E}$ stain, $\times 500$ $\mu \mathrm{m})$. AB, alveolar bone; GPA, greater palatine artery; GT, glandular tissue; LP, lamina propria; SM, submucosa.

Table 2. Topography of the GPA and the GPN according to tooth site

\begin{tabular}{|c|c|c|c|c|c|c|}
\hline & C $(n=7)$ & P1 $(n=7)$ & P2 $(n=11)$ & M1 (n=15) & M2 (n=9) & $\begin{array}{c}\text { Mean } \pm \text { standard } \\
\text { deviation }\end{array}$ \\
\hline Length of GPA & $8.7 \pm 1.9$ & $10.2 \pm 1.4$ & $11.0 \pm 1.6$ & $9.3 \pm 2.1$ & $11.2 \pm 1.9$ & $10.1 \pm 2.0$ \\
\hline Depth of GPA & $4.0 \pm 0.6^{\mathrm{a}}$ & $3.1 \pm 0.7^{\mathrm{b}}$ & $3.3 \pm 1.1^{\mathrm{c}}$ & $4.6 \pm 1.4^{\mathrm{d}}$ & $6.4 \pm 1.3^{\mathrm{abcd}}$ & $4.3 \pm 1.6$ \\
\hline Length of GPN & $9.5 \pm 1.2$ & $9.4 \pm 2.5$ & $11.9 \pm 1.5$ & $10.5 \pm 2.3$ & $11.6 \pm 2.8$ & $10.8 \pm 2.3$ \\
\hline Depth of GPN & $3.5 \pm 1.4$ & $2.8 \pm 0.6^{\mathrm{a}}$ & $2.4 \pm 0.7^{\mathrm{b}}$ & $3.9 \pm 1.3^{c}$ & $5.6 \pm 1.6^{\mathrm{abc}}$ & $3.7 \pm 1.6$ \\
\hline
\end{tabular}

Data (in millimeters) are mean \pm standard deviation values.

GPA, greater palatine artery; GPN, greater palatine nerve; C, canine; P1, first premolar; P2, second premolar; M1, first molar; M2, second molar; Length, distance from the alveolar crest to the center of the GPA and GPN; Depth, distance from the surface of the palatal mucosa to the center of the GPA and GPN.

abcd Identical superscripted letters indicate statistically significant differences among the tooth sites at the indicated measurement item $(p<0.05)$. 

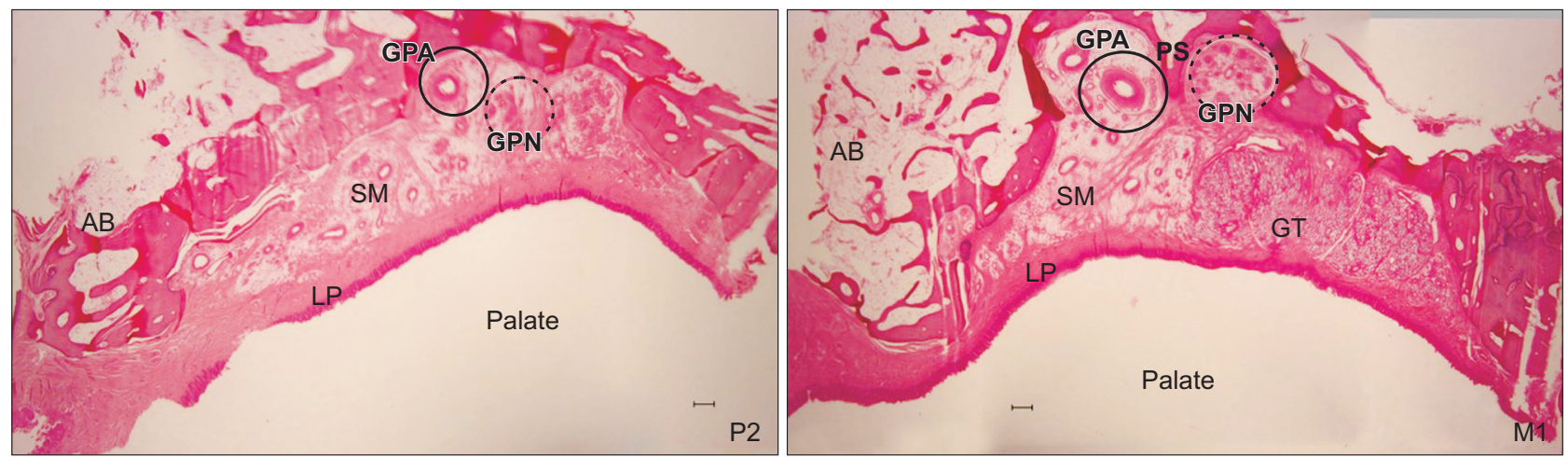

Fig. 3. Serial histologic sections of the palatal mucosa showing the topographic relationship of the GPA and the GPN based on the PS (H\&E stain, $\times 500 \mu \mathrm{m}$ ). P2, second premolar; M1, first molar; GPA, greater palatine artery; GPN, greater palatine nerve; AB, alveolar bone; SM, submucosa; LP, lamina propria; PS, palatal spine; GT, glandular tissue.

그 이후 큰입천장동맥과 큰입천장신경은 둘 모두 첫째 큰어금 니에서 이틀능선에 더 가까이 위치하였다가 작은어금니 부위에 서 멀어졌다 송곳니에서 급격히 가까워지는 양상을 보였다. 또 한 둘 모두 큰어금니에서 작은어금니로 갈수록 점막 표면 가까 이 주행하다 송곳니에서 다시 깊어졌다(Table 2).

\section{고 찰}

입천장 점막과 잇몸은 둘 모두 단단하고 가동성이 없으며, 조 직학적으로 유사한 특징을 가진다[1,4]. 이러한 이유로 단단입 천장은 치주 수술 및 눈꺼풀의 검판과 결막 재건과 같은 다양한 임상 술식에서 결합조직 이식을 위한 자가 이식 공여 부위로 사 용된다[5,6,19-21]. 성공적인 수술과 적절한 두께의 결합조직 이식편을 얻기에 가장 추천되는 부위는 송곳니 원심면에서 첫 째 큰어금니 정중선까지로, 큰입천장동맥을 주의하여 최대 길 이 $9.3 \mathrm{~mm}$ 두께 $4.0 \mathrm{~mm}$ 의 이식편을 얻을 수 있다[11,22,23]. 이때 생착과 지지에 중요한 고유판은 일정하고 풍부한 두께를 얻고, 치유와 혈관 형성을 방해하는 지방조직이나 샘조직은 그 양을 적게 하는 것이 중요하다[6,19,20]. 그러나 고유판은 점막 밑층과 반대로 정중입천장봉합 및 후방 치아로 갈수록 두께가 감소하고[11,12], 큰입천장동맥은 여러 가지를 내며 신경과 다 른 경로를 가진다[18]. 따라서 입천장 점막의 고유판, 지방조직 및 샘조직의 분포와 구성에 관한 정량적 자료와 큰입천장동맥 과 큰입천장신경의 중심가지의 위치 관계에 관한 명확한 이해 가 요구된다.

본 연구에서 전체 입천장 점막과 점막밑층의 평균 면적은 모 두 송곳니에서부터 둘째 작은어금니까지 면적이 감소하다가, 후방 큰어금니로 갈수록 샘조직이 통계적으로 유의적으로 증가 함에 따라 그 면적이 크게 증가하였다. 이러한 결과는 입천장 점
막의 두께를 계측한 이전 연구 결과와 치아의 위치에 따라 유사 한 양상으로 나타나[8,11], 면적과 두께에 관한 점막의 입체적 크기가 관련성이 있음을 알 수 있다. 송곳니 원심면에서부터 샘 조직이 게재된다는 연구 결과가 있지만[11], 본 연구에서 둘째 작은어금니 11 쪽 중 2쪽에서만 샘조직이 발견되어, 작은어금니 부위는 일정한 면적의 비율(0.34)을 가지는 고유판과 지방조직 으로 이루어진 점막밑층으로 구성되었음을 알 수 있다. 또한 송 곳니에서는 작은어금니에 비하여 증가된 점막 면적과 점막밑 층의 비율 감소를 보여 Cho 등[24]의 연구 결과와 동일하게 고 유판의 양이 상대적으로 많았다. 이는 씹기를 보조하고 발음에 중요한 입천장 가로주름(palatal rugae)의 형성으로 볼 수 있다 [11,25].

Sullivan과 Atkins [19]는 입천장을 입천장쪽 이틀돌기 위의 잇몸부위(gingival zone) 및 입천장 신경혈관다발 위에서 후 방 어금니의 샘조직부위(glandular zone)와 전방의 지방조직 부위(fatty zone)로 구분하였다. 본 연구에서도 첫째 큰어금니 에서 0.26 의 비율로 샘조직이 나타나기 시작해 둘째 큰어금니 에서 비율이 0.41 로 크게 증가하면서 동시에 전체 점막의 면적 도 증가하였다. 즉 샘조직은 그 짧은 도관이 열리는 입천장오목 (palatine fovea) 가까운 큰어금니 부위에 집중되어 있다고 할 수 있다. 큰어금니 부위의 이러한 전체 입천장 점막 면적의 증가 는 샘조직의 급격한 증가와 더불어 치열궁의 형태에서 기인하 였다고 할 수 있다. 따라서 큰 이식편을 얻기 위한 정중입천장 봉합, 후방어금니 및 뼈막을 향한 넓고, 길고, 깊은 절개는 상대 적으로 고유판의 양은 감소하고 큰어금니에서는 샘조직이 둘째 작은어금니부터 앞쪽으로는 지방조직의 비율만 증가한다고 할 수 있다[2,11].

또한 이러한 씹기점막은 식이에 따른 반복적 자극으로 연 령 증가에 따라 각화상피층의 두께는 증가하고 샘조직은 위 
축된다고 하였지만[3,26], 성별, 연령 및 체중에 따른 입천 장 점막 두께의 통계적 유의적 차이에 관한 의견이 분분하다 $[3,7,8,10,22,27]$. 따라서 시신을 이용한 본 연구에서 큰어금니 부위의 샘조직의 높은 비율은 연령 증가에 따른 구강의 주요 침 샘이 위축되어도 치밀 결합조직 아래에서 그 역할을 유지할 것 을 기대되어 이에 관한 추가 연구가 필요하다.

이러한 입천장 점막에 분포하는 신경혈관다발을 $\mathrm{Yu}$ 등[18] 이 제시한 입천장쪽 잇몸에 분포하며 중심을 이루는 가쪽가지 를 기준으로 살펴본 결과, 큰입천장구멍에서 시작하는 둘째 큰 어금니에서는 입천장가시를 기준으로 큰입천장동맥은 가쪽고 랑에 큰입천장신경은 안쪽고랑에 위치하였다. 이후 큰입천장동 맥은 평균 $10.1 \mathrm{~mm}$ 로 큰입천장신경의 평균 $10.8 \mathrm{~mm}$ 보다 이 틀능선에 가까운 신경보다 가쪽에 위치하였으나 통계적으로 유 의하지는 않았고, 반면 깊이에 있어서는 동맥이 평균 $4.3 \mathrm{~mm}$ 로 신경의 평균 $3.7 \mathrm{~mm}$ 보다 통계적으로 유의하게 점막 표면에서 깊이 위치하였다. 또한 큰입천장동맥은 신경보다 상대적으로 큰 직경과 많은 분지를 내고, 단단입천장의 후방부는 전방부 보 다 감각이 덜 예민하다[1]. 따라서 절개 시 얕은 위치에 있는 신 경이 먼저 손상될 가능성이 있으나, 공여 부위의 이식편의 획득 과 치유 과정에 문제가 되지 않을 것으로 사료된다.

큰입천장동맥은 이식편의 크기를 결정하는 중요한 제한 요 인으로, 큰어금니부위에서 약 $10 \mathrm{~mm}$ 길이로 존재하는 입천 장가시의 가쪽고랑을 따라 백악법랑경계(cementoenamel junction)로부터 둘째 큰어금니의 약 $14 \mathrm{~mm}$ 거리에서 앞쪽으 로 점점 감소하여 송곳니의 약 $9 \mathrm{~mm}$ 거리에 위치하여 뼈구조물 인 입천창가시의 촉진과 방사선 사진을 판독을 통하여 그 경로 를 예측할 수 있다[18,23,28]. 본 연구에서도 입천장가시와 가 쪽고랑의 위치를 확인할 수 있었고 이전 연구와 유사한 경로를 보였으나, 이틀능선의 기준점 및 가쪽가지의 기준 설계로 이전 연구보다 더 작은 수치로 나타났다. 특히 첫째 큰어금니에서 입 천장쪽 치아 뿌리로 인한 뭉툭한 이틀돌기의 형성으로 동맥이 이틀능선에 더 가까이 위치하였다. 또한 점막표면으로 깊이는 이전 연구 결과와 유사하게 샘조직이 위치하는 큰어금니부위에 서는 깊이 위치하였다가 앞니로 갈수록 얕게 위치하여 주의가 더 요구된다[23,24]. 이처럼 큰입천장동맥은 단단입천장 시술 시 주의가 필요함에도 불구하고, 큰어금니부위에서 높은 비율 의 샘조직 존재로 입천장가시의 촉진이 어렵고 더불어 입천장 의 높이 따라 동맥의 위치가 7-17 $\mathrm{mm}$ 로 변이가 심하게 나타나 므로, 임상의는 술전 치료 계획에서 큰입천장동맥의 주행과 위 치에 관한 정확한 해부학적 지식을 갖추고 평가하여야 한다.

결론적으로, 입천장 점막은 작은어금니부위에서 일정한 고유 판을 가지며 큰입천장동맥 위의 지방조직으로 이루어져 샤피섬 유가 샘조직의 게재 없이 뼈막에서 고유판을 수직으로 단단히
잡고 있으며, 큰어금니부위는 샘조직이 큰 면적을 차지하고 반 면 고유판의 양은 감소하였다. 또한 입천장쪽 잇몸에 분지하며 중심을 이루며 분포하는 큰입천장동맥과 큰입천장신경은 가쪽 고랑을 따라 이틀능선 아래 약 $10 \mathrm{~mm}$ 위치에서 주행하며, 동맥 은 신경보다 점막 표면에서 깊이 위치하였다. 따라서 이러한 입 천장 점막의 고유판, 지방조직 및 샘조직의 분포와 구성 및 큰입 천장동맥과 큰입천장신경의 주행과 위치 관계에 관한 조직형태 학적 분석 결과는 결합조직 이식을 위한 자가 이식 공여 부위로 서 입천장 점막에 관한 정량적 자료를 제공할 수 있다.

\section{ACKNOWLEDGEMENTS}

This study was supported by research fund from Chosun University, 2015.

\section{CONFLICTS OF INTEREST}

The authors declare that they have no competing interests.

\section{ORCID}

\author{
Sun-Kyoung Yu \\ https://orcid.org/0000-0003-0801-1663 \\ Jin Woong Lim \\ https://orcid.org/0000-0001-6735-555X \\ Yonghwa Cho \\ https://orcid.org/0000-0001-8053-8289 \\ Heung-Joong Kim \\ https://orcid.org/0000-0003-1636-3669
}

\section{REFERENCES}

1. Nanci A. Ten cate's oral histology: development, structure, and function. 8th ed. Seoul: Daehan Publishing Co; 2014.

2. Harris RJ. Histologic evaluation of connective tissue grafts in humans. Int J Periodontics Restorative Dent 2003;23: 575-583. doi: 10.11607/prd.00.0552.

3. Lee YJ, Kwon YH, Park JB, Herr Y, Shin SI, Heo SJ, Chung JH. Epithelial thickness of the palatal mucosa: a histomorphometric study in Koreans. Anat Rec (Hoboken) 2010;293:1966-1970. doi: 10.1002/ar.21249.

4. Ciano J, Beatty BL. Regional quantitative histological variations in human oral mucosa. Anat Rec (Hoboken) 2015;298:562-578. doi: 10.1002/ar.23097. 
5. Ito R, Fujiwara M, Nagasako R. Hard palate mucoperiosteal graft for posterior lamellar reconstruction of the upper eyelid: histologic rationale. J Craniofac Surg 2007;18:684690. doi: 10.1097/scs.0b013e318053446d.

6. Mörmann W, Schaer F, Firestone AR. The relationship between success of free gingival grafts and transplant thickness. Revascularization and shrinkage-a one year clinical study. J Periodontol 1981;52:74-80. doi: 10.1902/ jop.1981.52.2.74.

7. Studer SP, Allen EP, Rees TC, Kouba A. The thickness of masticatory mucosa in the human hard palate and tuberosity as potential donor sites for ridge augmentation procedures. J Periodontol 1997;68:145-151. doi: 10.1902/ jop.1997.68.2.145.

8. Song JE, Um YJ, Kim CS, Choi SH, Cho KS, Kim CK, Chai JK, Jung UW. Thickness of posterior palatal masticatory mucosa: the use of computerized tomography. J Periodontol 2008;79:406-412. doi: 10.1902/jop.2008.070302.

9. Müller HP, Schaller N, Eger T. Ultrasonic determination of thickness of masticatory mucosa: a methodologic study. Oral Surg Oral Med Oral Pathol Oral Radiol Endod 1999;88: 248-253. doi: 10.1016/S1079-2104(99)70123-X.

10. Heil A, Schwindling FS, Jelinek C, Fischer M, Prager M, Lazo Gonzalez E, Bendszus M, Heiland S, Hilgenfeld T. Determination of the palatal masticatory mucosa thickness by dental MRI: a prospective study analysing age and gender effects. Dentomaxillofac Radiol 2018;47:20170282. doi: $10.1259 / \mathrm{dmfr} .20170282$

11. Yu SK, Lee MH, Kim CS, Kim DK, Kim HJ. Thickness of the palatal masticatory mucosa with reference to autogenous grafting: a cadaveric and histologic study. Int J Periodontics Restorative Dent 2014;34:115-121. doi: 10.11607/prd.15 30.

12. Yu SK, Lee BH, Lee MH, Cho KH, Kim DK, Kim HJ. Histomorphometric analysis of the palatal mucosa associated with periodontal plastic surgery on cadavers. Surg Radiol Anat 2013;35:463-469. doi: 10.1007/s00276012-1066-0.

13. Greenstein G, Cavallaro J, Tarnow D. Practical application of anatomy for the dental implant surgeon. J Periodontol 2008;79:1833-1846. doi: 10.1902/jop.2008.080086.

14. Reiser GM, Bruno JF, Mahan PE, Larkin LH. The subepithelial connective tissue graft palatal donor site: anatomic considerations for surgeons. Int J Periodontics Restorative Dent 1996;16:130-137. doi: 10.11607/prd.00. 0167.

15. Lee KY, Lee MH, Yu SK, Jeong GS, Kim HJ. The relative location of the greater palatine foramen in Koreans. Oral Biol Res 2012;36:14-18.

16. Benninger B, Andrews K, Carter W. Clinical measurements of hard palate and implications for subepithelial connective tissue grafts with suggestions for palatal nomenclature. J Oral Maxillofac Surg 2012;70:149-153. doi: 10.1016/j.jo ms.2011.03.066.

17. Hassanali J, Mwaniki D. Palatal analysis and osteology of the hard palate of the Kenyan African skulls. Anat Rec 1984;209:273-280. doi: 10.1002/ar.1092090213.

18. Yu SK, Lee MH, Park BS, Jeon YH, Chung YY, Kim HJ. Topographical relationship of the greater palatine artery and the palatal spine. Significance for periodontal surgery. J Clin Periodontol 2014;41:908-913. doi: 10.1111/jcpe. 12288.

19. Sullivan HC, Atkins JH. Freeutogenous gingival grafts. 1. Principles of successful grafting. Periodontics 1968;6:5-13.

20. Langer L, Langer B. The subepithelial connective tissue graft for treatment of gingival recession. Dent Clin North Am 1993;37:243-264.

21. Wearne MJ, Sandy C, Rose GE, Pitts J, Collin JR. Autogenous hard palate mucosa: the ideal lower eyelid spacer? Br J Ophthalmol 2001;85:1183-1187. doi: 10.1136/bjo.85.10. 1183.

22. Yaman D, Aksu S, Dişçi R, Demirel K. Thickness of palatal masticatory mucosa and its relationship with different parameters in Turkish subjects. Int J Med Sci 2014;11: 1009-1014. doi: 10.7150/ijms.9112.

23. Kim DH, Won SY, Bae JH, Jung UW, Park DS, Kim HJ, Hu KS. Topography of the greater palatine artery and the palatal vault for various types of periodontal plastic surgery. Clin Anat 2014;27:578-584. doi: 10.1002/ca. 22252.

24. Cho KH, Yu SK, Lee MH, Lee DS, Kim HJ. Histological assessment of the palatal mucosa and greater palatine artery with reference to subepithelial connective tissue grafting. Anat Cell Biol 2013;46:171-176. doi: 10.5115/ac b.2013.46.3.171.

25. Patil MS, Patil SB ,Acharya AB. Palatine rugae and their significance in clinical dentistry: a review of the literature. J Am Dent Assoc 2008;139:1471-1478. doi: 10.14219/jada. archive.2008.0072.

26. Kolliyavar B, Setty S, Thakur SL. Determination of thickness of palatal mucosa. J Indian Soc Periodontol 2012;16:80-83. doi: 10.4103/0972-124X.94610.

27. Stipetić J, Hrala Z, Celebić A. Thickness of masticatory mucosa in the human hard palate and tuberosity dependent on gender and body mass index. Coll Antropol 2005;29:243-247.

28. Klosek SK, Rungruang T. Anatomical study of the greater palatine artery and related structures of the palatal vault: considerations for palate as the subepithelial connective tissue graft donor site. Surg Radiol Anat 2009;31:245-250. doi: 10.1007/s00276-008-0432-4. 